\section{AUTHORS:}

Jennifer M. Fitchett ${ }^{1}$

Stefan W. Grab ${ }^{1}$ iD

Heinrich Portwig ${ }^{1}$

\section{AFFILIATION:}

${ }^{1}$ School of Geography, Archaeology and Environmental Studies, University of the Witwatersrand, Johannesburg, South Africa

CORRESPONDENCE TO: Jennifer Fitchett

EMAIL:

jennifer.m.fitchett@gmail.com

\section{DATES:}

Received: 20 Dec. 2018

Revised: 24 Mar. 2019

Accepted: 26 Mar. 2019

Published: 30 July 2019

\section{HOW TO CITE:}

Fitchett JM, Grab SW, Portwig

$H$. Progressive delays in the

timing of sardine migration in the

southwest Indian Ocean. S Afr J

Sci. 2019;115(7/8), Art. \#5887,

6 pages. https://doi.org/10.17159/

sajs.2019/5887

\section{ARTICLE INCLUDES:}

囚 Peer review

$\square$ Supplementary material

\section{DATA AVAILABILITY:}

$\square$ Open data set

$\square$ All data included

冈 On request from author(s)

$\square$ Not available

$\square$ Not applicable

\section{EDITORS:}

John Butler-Adam (iD

\section{KEYWORDS:}

phenology; sardine run; sea surface temperature; ENSO; mid-latitude

cyclones

FUNDING:

None

\title{
Progressive delays in the timing of sardine migration in the southwest Indian Ocean
}

Phenological shifts represent one of the most robust bioindicators of climate change. While considerable
multidecadal records of plant and animal phenology exist for the northern hemisphere, few noteworthy
records are available for the southern hemisphere. We present one of the first phenological records of fish
migration for the southern hemisphere, and one of the only phenological records for the southwest Indian
Ocean. The so-called 'sardine run' - an annual winter migration of sardines, northeast of their summer
spawning grounds on the Agulhas Bank off the coast of Durban, South Africa - has been well documented
in local newspapers given the importance placed on fishing and fishing-tourism in the region. An analysis of
the first arrival dates of sardines reveals a 1.3 day per decade delay over the period 1946-2012. Although
this phenological shift reveals a poor association with sea surface temperatures (SST), it coincides with
a poleward shift in the position of the $21^{\circ} \mathrm{C}$ mean annual SST isotherm - the threshold temperature for
sardine populations. The timing of sardine arrivals near Durban corresponds closely with the number of
mid-latitude cyclones passing over the Durban coastline during the months of April and May. The strength
of the run is strongly associated with ENSO conditions. The complex suite of factors associated with this
phenological shift poses challenges in accurately modelling the future trajectory for this migratory event.

\section{Significance:}

- The sardine run, a significant event for tourism and fisheries, is occurring progressively later in the year.

- The incidence of failed sardine runs has increased in frequency over the period 1946-2012.

- These changes in fish migration phenology coincide with a poleward shift in the position of the $21^{\circ} \mathrm{C}$ mean annual SST isotherm.

- The strength in the sardine run is strongly associated with ENSO conditions.

\section{Introduction}

Shifts in the timing of floral and faunal phenological events are cited as one of the most robust bioindicators of climate change. ${ }^{1}$ A substantial body of literature has highlighted both advances and delays in phenological events as a direct response to global scale warming over recent decades. ${ }^{2-5}$ These meta-analyses have confirmed, most importantly, that such shifts are both location and species specific in nature. ${ }^{6}$ This in turn results in mismatches between flowers and pollinators ${ }^{7,8}$; predators and prey ${ }^{9,10}$; and food supply (or food peaks) and demand during breeding and feeding young offspring ${ }^{11,12}$. The importance of a high spatial resolution network of phenological observations spanning a wide range of plant and animal species is thus magnified, both for the region and species, and for the global understanding of phenological responses to climate change. ${ }^{13}$

The timing of annual migrations and the extent of the range shifts captured therein represent an important phenological record due to the interaction of intrinsic and extrinsic cues. ${ }^{14,15}$ Given the range shift boundaries that are posed by anthropogenic infrastructural developments, overlapping predator ranges, and food availability, shifts in the timing and extent of annual migration often cannot transpire to the extent required by the intrinsic temperature-related cue of the species. Research on annual migration is hampered by the dynamic nature of the subject being observed. ${ }^{16}$ Unlike plants which remain in a fixed location throughout their lifespan, and which can thus be observed daily on an individual basis, migratory events can often only be measured for the migrating population as a whole. ${ }^{17}$ Moreover, unless tracking devices are used, the phenological record of the migration event is usually captured using proxies for the appearance of the population at a destination along the migratory route, such as bird and frog calls or evidence of nest construction. ${ }^{18,19}$ These proxies, captured over a longitudinal time span, are then compared against the climatic conditions at that destination, to determine the phenological shifts under changing climatic conditions. ${ }^{2,19}$

The 'sardine run' is an annual eastward migration of sardines from the Agulhas Bank off the southern coast of South Africa (Figure 1) in early (austral) winter. ${ }^{20,21}$ Sardines are small pelagic fish belonging to the order Clupeiformes, with the South African sardine Sardinops sagax being the focus of the current study. South African sardine subpopulations, which thrive under ocean temperatures of $21^{\circ} \mathrm{C}$, are constrained to waters poleward of $\sim 32^{\circ} \mathrm{S}$ during the summer months, with the exception of the west coast which is influenced by cold, deep water upwelling through Ekman transport, driven by the Benguela current..$^{21}$ In winter, as the $21^{\circ} \mathrm{C}$ isotherm shifts northwards, the sardines' range is expanded up the east coast of the country. ${ }^{22}$ Evidence from coastal sampling suggests that the east coast region of South Africa serves as a spawning ground during the winter months. ${ }^{23}$

This distinct seasonal migration is a feature of the geographical position of South Africa. Situated at the boundary of the subtropics and mid-latitudes, South Africa is influenced by significant seasonal fluctuations. During winter months, the climate of the southern half of the country is controlled by the frequent passage of mid-latitude cyclones, whereas convective systems characterise precipitation in the northern interior during summer months. ${ }^{24,25}$ The latitudinal position of the westerlies, and in turn the potential for the northern progression of mid-latitude cyclones ${ }^{25}$, more directly influences the oceanographic conditions along the east coast of South Africa through responses in the Agulhas leakage ${ }^{26}$. However, factors encouraging their seasonal migration are poorly understood, particularly as the region remains populated by predators such as sharks, and has a thermally restricted plankton abundance which limits food supply. ${ }^{20,27}$ Similar
(C) 2019. The Author(s). Published under a Creative Commons Attribution Licence. 
seasonal migration patterns, range shifts and population size changes in sardines have been reported for Sweden ${ }^{28,29}$, Chile $^{30}$ and the Pacific Ocean more broadly $\mathrm{y}^{31,32}$. The role of climate change in altering these population behavioural characteristics has been considered at both global and regional scales $^{33}$, including the importance of El Niño Southern Oscillation (ENSO) and the frequency and intensity of mid-latitude cyclones ${ }^{32}$.

The sardine run has received considerable media attention for more than 150 years in and near the city of Durban on the east coast of South Africa. The sudden migration of sardines results in favourable fishing conditions in a region otherwise too warm for this species, and the heightened shark, dolphin and penguin activity in the region serves as a tourist attraction. ${ }^{27,34}$ Newspapers contain a rich, temporally constrained record of the annual sardine migration, which to date has not been explored. To this end, we investigated this record for the region, over the period 1947-2010. In so doing, we aimed to quantify the phenological shift of the sardine run over the given period, and interrogate a range of ocean-atmospheric factors that may explain any changes in the timing of this phenological event in the context of global climate change related phenological shifts.

\section{Materials and methods}

The phenological record of annually northeastward migrating sardines in early (austral) winter was constructed using articles from three newspapers published in the Durban and South Coast region of KwaZuluNatal Province, South Africa: South Coast Sun (1999-2006), South Coast Herald (1949-1998, 2006-2012) and the Natal Mercury (1852-1949). These newspapers are archived in the National Library of South Africa, and all issues of the newspaper spanning April to August each year were consulted in the archive. The South Coast Sun and South Coast Herald were weekly publications. Most records of sardine sightings were obtained from the South Coast Herald, which was published every Friday. The Natal Mercury was printed as a weekly to twice weekly publication until 1878; from 2 January 1878 it became a daily publication (it has since become the Mercury). These newspapers record specific days when the run occurred, by referring to the event on a specific date. Given that the sardine run events are notable 'public' or 'social' events of much interest on a given day, there is a relatively high level of accuracy in the dates recorded. However, as with any documentary source, an inherent margin of error exists in both the specificity of the start date, and the reliability of annual recordings.

Early newspaper accounts of the sardine run spanning 1852-1945 are sporadic, and thus cannot be included in any meaningful statistical analysis. These do, however, reflect the prolonged occurrence of this phenological event in the region. More recent newspaper reports include a richer array of descriptions, including the size of the shoal, the human interest, and comparison between events:

Hundreds of cars from far and wide poured in and out Port Edward looking for sardines, huge shoals and thousands of birds spotted at Port Edward on Sunday.

\section{South Coast Herald, 30 June 1961}

Our photographer was at Portobello beach last weekend when the mammoth 1971 sardine run began, already it has been the biggest sardine run in 8 years say some experts, others claim there haven't been so many of the fish since 1959.

\section{South Coast Herald, 25 June 1971}

From the newspaper records spanning 1946-2012, all but two years contained mention of the sardine run. From these reports, the first report of the sardine run for each year was captured, together with quotes containing commentary relating to the size of the run. Calendar dates were converted to Julian dates for analysis. ${ }^{19}$ The rate of change in the timing of the sardine run was calculated using standard univariate linear regression analysis in the form $y=m x+c .{ }^{19}$ Commentary pertaining to the size of the run was qualitatively grouped using content analysis.

To determine the role of climatic change in driving the phenological shift, the annual dates of the first recorded sardine runs in Durban were compared against mean sea surface temperatures (SST) at Port St Johns (Figure 1), acquired from the NOAA extended SST database (www.esrl. noaa.gov/psd/data/gridded/data.noaa.ersst.html), using Pearson's correlation coefficient. ${ }^{19}$ Long-term trends in the latitudinal position of the $21^{\circ} \mathrm{C}$ SST isotherm, the threshold condition for sardine range, were qualitatively explored through developing a composite plot of the decadal mean annual sea surface isotherms from the NOAA Extended V4 GrADS images (https://www.esrl.noaa.gov/psd/data/gridded/data. noaa.ersst.v4.html). The $21^{\circ} \mathrm{C}$ isotherm was extracted for each decade and these were overlaid for the period 1941-2010.35,36 To explore the role of mid-latitude cyclone occurrence in determining the Julian date of sardine arrival off the coast of Durban ${ }^{32}$, monthly counts of mid-latitude cyclone incursion to, or over, the Durban region were captured from daily synoptic maps produced by the South African Weather Service spanning $0-70^{\circ} \mathrm{S}, 60^{\circ} \mathrm{W}-80^{\circ} \mathrm{E}$. A sum of mid-latitude cyclones for the months of April and May was then compared statistically to the arrival dates using Pearson's correlation coefficient, and the range of arrival dates per number of mid-latitude cyclones were compared using five-number summaries (maximum, minimum, first and third quartiles, median and outliers) produced in box-plot format. To explore the relationship between the sardine arrival date and ENSO ${ }^{32}$, Multivariate ENSO Index (MEl) values were obtained (https://www.esrl.noaa.gov/psd/enso/ mei/) and compared to the arrival dates using Pearson's correlation coefficient. The mean annual MEI values were then displayed as a time series, against which the newspaper-reported occurrences of 'good', 'poor' and 'absent' sardine migration events were plotted, to determine concurrent ENSO and anomalous migration events.

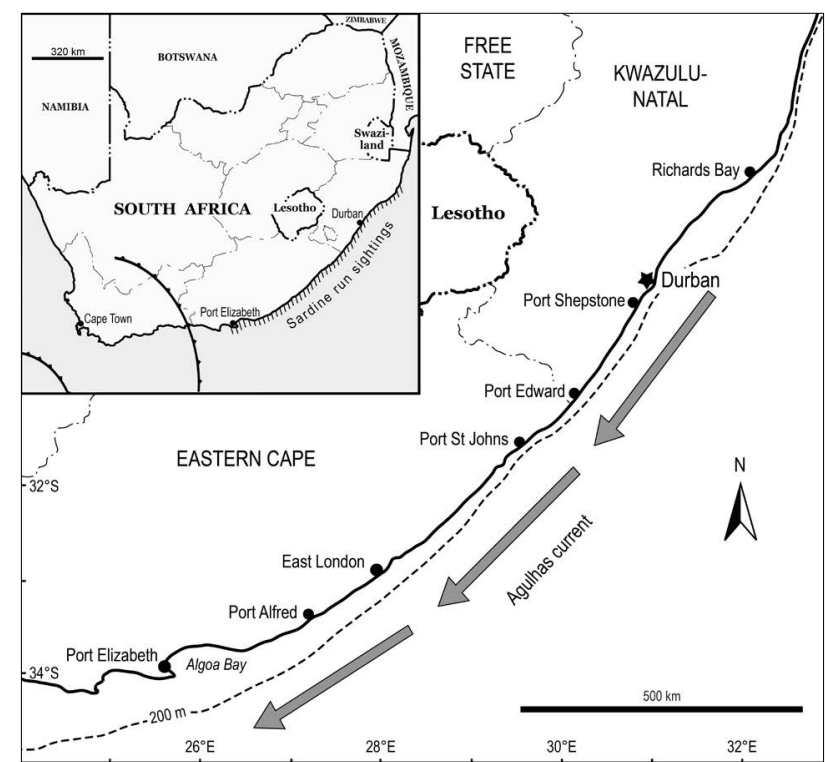

Figure 1: Map of southern Africa indicating the east coast of South Africa along which the sardine runs are sighted (see hashed zone along the coast), and the winter mean trajectory of mid-latitude cyclones (barbed line). The 200-m isobath indicates the extent of the continental shelf.

\section{Results}

A progressive delay is noted in the first mention of annual sardine runs in the Durban region, for the period 1947-2012 (Figure 2). This delay in arrival date occurs at a mean rate of 0.13 days per year $(r=0.23$, $p=0.07$, d.f. $=64)$, or 1.3 days per decade, and represents a shift in the arrival date from a mean Julian date of 161 ( June 10) for the first decade of the data set to a mean Julian date of 173 ( June 22) for the most recent decade of the data set. The latest arrival dates were recorded for the years $1978(J D=204)$ and $2006(J D=203)$, while the earliest arrival dates were recorded for 1949 and 1967 (both $J D=146$ ) and $1984(\mathrm{JD}=147)$. The variability in the date of arrival has increased over time (Figure 2), from a relatively low standard deviation for the period $1947-1965(\sigma=6.2)$, with a $204 \%$ increase in variability for the 


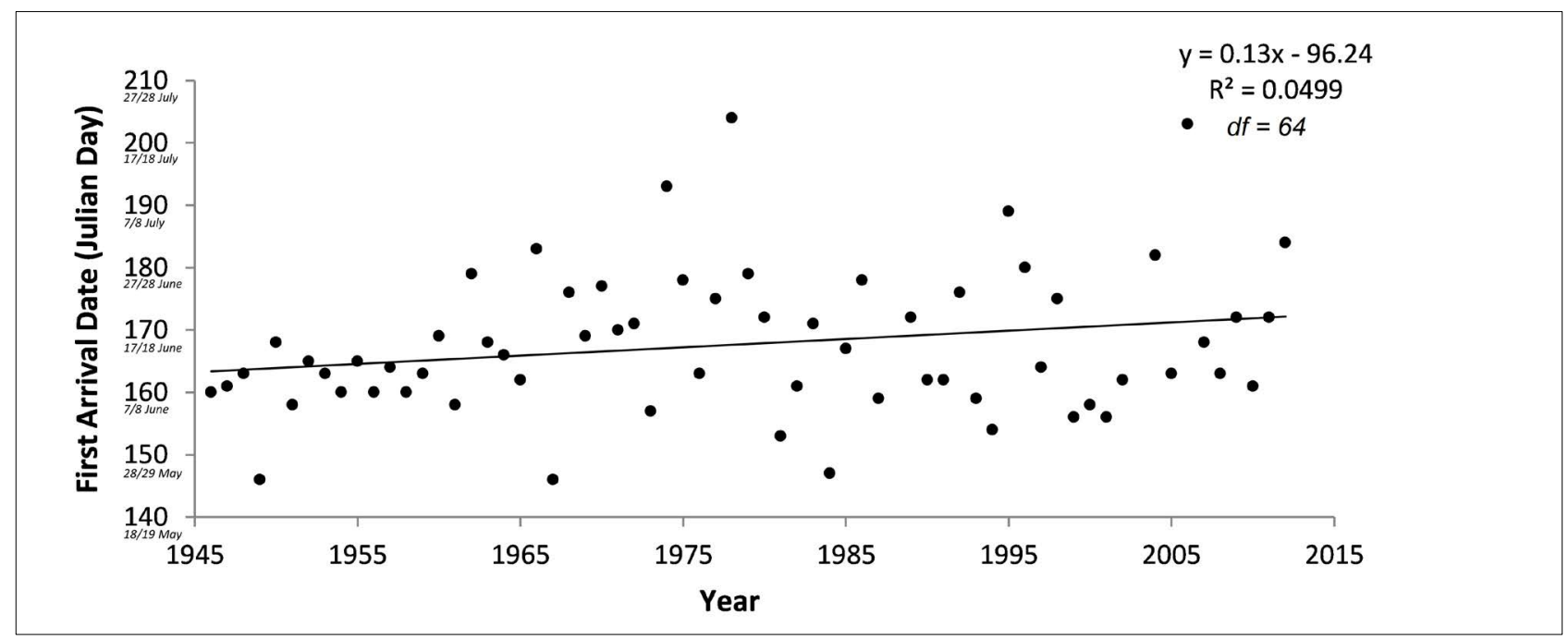

Figure 2: $\quad$ Phenological shift in the start date of the sardine migration in the southwest Indian Ocean over the period $1946-2014$.

consecutive period 1966-2014 $(\sigma=12.7)$. The greatest variability in sardine arrival date is observed for the period 1967-1984 ( $\sigma=14.63)$, with markedly lower variability thereafter, centred around a mean arrival Julian date of $169(\sigma=11.77)$.

Statistically significant time trends in mean monthly SST for the Durban region spanning 1946-2012 were calculated for the months of May, June and July, and the mean winter period at a rate of $0.01^{\circ} \mathrm{C} /$ year (Table 1).

Table 1: Time trend in mean monthly sea surface temperature (SST) at Port St Johns for the months of May, June and July, and Pearson's correlation coefficient values for the comparison with sardine arrival date $(1946-2012$, d.f. $=64)$

\begin{tabular}{l|l|l|l|l}
\hline \hline & \multicolumn{1}{c|}{ May } & \multicolumn{1}{c|}{ June } & \multicolumn{1}{c|}{ July } & \multicolumn{1}{c}{ Winter mean } \\
\hline \hline \multirow{3}{*}{ SST Time trend } & $0.01 \%$ year & $0.01 \%$ year & $0.01 \%$ year & $0.01 \%$ year \\
\cline { 2 - 5 } & $r=0.58$ & $r=0.64$ & $r=0.55$ & $r=0.65$ \\
\cline { 2 - 5 } & $p<0.0001$ & $p<0.0001$ & $p<0.0001$ & $p<0.0001$ \\
\hline Correlation with & $r=0.12$ & $r=0.21$ & $r=0.32$ & $r=0.24$ \\
\hline sardine arrival date & $p=0.2$ & $p=0.1$ & $p=0.01$ & $p=0.05$
\end{tabular}

Weak correlations were observed between the arrival dates of sardines in the Durban region and local mean annual ocean temperatures for the months of May $(r=0.12, p=0.3361$, d.f. $=64)$, June $(r=0.21, p=0.0932$, d.f. $=64)$ and July $(r=0.32, p=0.0087$, d.f. $=64)$ during which the sardine run occurs, with no statistically significant correlation between mean winter SST and the sardine run dates $(r=0.24, p=0.05$; Table 1$)$. However, concurrent with this phenological shift in arrival dates of migratory sardine populations along the south and east coasts of southern Africa, is a progressive poleward displacement of the $21^{\circ} \mathrm{C}$ isotherm from 1951 to 2010 (Figure 3).

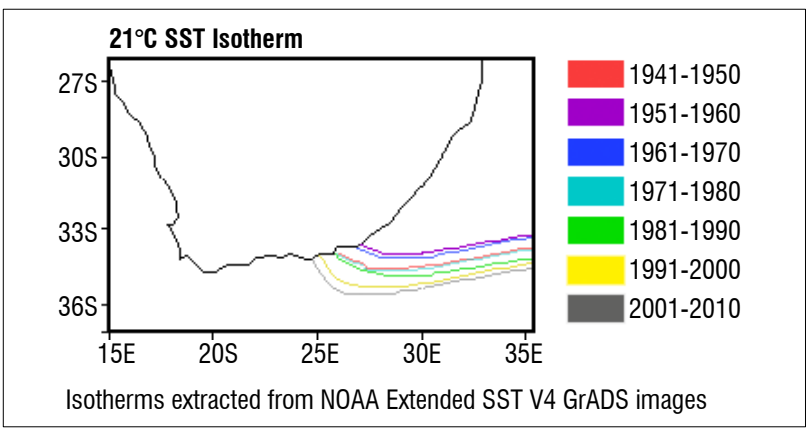

Figure 3: Poleward shift in the $21^{\circ} \mathrm{C}$ mean annual sea surface temperature (SST) isotherm over the period 1941-2010.
This displacement is significant as $21^{\circ} \mathrm{C}$ is the maximum threshold ocean temperature for sardines. The isotherm has shifted $1.5^{\circ}$ poleward since 1951 , which equates to a $0.25^{\circ}$ latitudinal shift per decade. Notably, the $21^{\circ} \mathrm{C}$ isotherm for the period $1941-1950$ is located $\sim 0.6^{\circ}$ south of the $21^{\circ} \mathrm{C}$ isotherm for the periods 1951-1960 and 1961-1970 (Figure 3). This finding may indicate a degree of interdecadal variability in the position of the $21^{\circ} \mathrm{C}$ isotherm, although the progressive poleward trend from 1951 onwards would suggest a continuous response to global scale warming during this period.

On average, 10 mid-latitude cyclones affect the Durban region during the months of April and May each year; 15 of the 58 years in the sample were characterised by six mid-latitude cyclones in the region during April and May. A statistically significant relationship exists between the number of mid-latitude cyclones experienced during April and May and the arrival date of sardines in the region $(r=0.37, p<0.005$, d.f. $=67)$. By classifying sardine arrival dates according to the number of midlatitude cyclones during the preceding months of April and May, the effect of this discrete variable can be considered. A progressive delay in arrival date corresponds with an increase in the number of mid-latitude cyclones, at a rate of 2.4 days per additional cyclone (Figure 4).

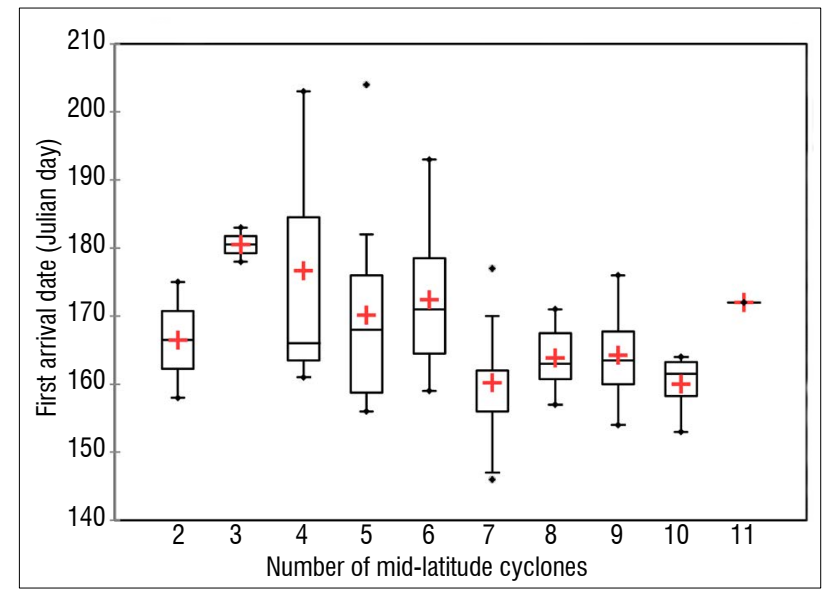

Figure 4: Arrival date of sardines classified by the number of mid-latitude cyclones. Central line represents the median value; crosses indicate the mean score.

A particular exception to this relationship is the occurrence of 11 midlatitude cyclones in the region during April and May of 1980, with a significantly later first arrival date. In addition, years with only two midlatitude cyclones in April and May, had notably earlier first arrival dates (Figure 4). These exceptions at the extremes may be indicative of errors 
in the attribution of mid-latitude cyclone conditions, particularly in the earlier records.

No statistical correlation exists between the first arrival date of sardines and the MEI score $(r=0.02, p=0.4256)$. However, a degree of correspondence is observed when plotting the sardine run migration events that were reported in the newspaper articles as explicitly 'good' or 'strong', 'weak' or 'poor', and the instances of no sardine run occurring against mean annual MEl over the period 1946-2012 (Figure 5). Years with a poor run or no run correspond with the majority of the positive MEl scores (El Niño events), whereas years with a good run correspond in most instances with negative MEl scores (La Niña events).

Multiple regression analysis to determine the combined effect of this collection of variables on sardine arrival dates returned a statistically insignificant model capable of explaining only $16.90 \%$ of the variance $(p=0.0783)$, defined by the equation:

Arrival date $=89.37-1.48$ [mid-latitude cyclone count] -5.51 [SST $_{\text {May }}$ ] $-3.80\left[\mathrm{SST}_{\text {June }}\right]+13.77\left[\mathrm{SST}_{\text {July }}\right]+0.41\left[\right.$ ENSO $_{\text {. }}$

\section{Discussion and conclusion}

Phenological shifts in the timing of first observation of migratory species represent a key biometeorological indicator of faunal responses to climate change. ${ }^{2,14}$ With the significance of migration timing to interand intra-species overlap, it is also one of the phenological shifts most likely to disrupt entire ecosystems following relatively small climatic changes.$^{10}$ However, there remain relatively few studies exploring shifts in the timing of migratory fish species ${ }^{37-40}$, and in particular that for sardines. Given the importance of this species for global fisheries ${ }^{41,42}$, an improved understanding of the temporal and spatial variability in the phenological response to warming atmospheric and oceanic temperatures is imperative ${ }^{20}$. For the southern African sardine run in particular, the poorly understood interannual variability in the timing of the event is frequently cited as a threat to the sustained economic benefit from the event through increased fishing opportunities and tourism. ${ }^{21,23,34}$ The long-term progressive delay in the sardine arrival date places this interannual variability into context of longer-term shifts in the phenology, which in turn facilitates better monitoring and modelling of this event. However, the heightened variability in the timing over recent decades, and, in particular, the recent failures of the event pose a concerning outlook for sardine populations in the region.

Phenological shifts, for both plant and animal species, are often related directly to changes in local air temperature. ${ }^{2,17,18}$ For marine species, SSTs and ocean-atmospheric interactions have a more direct impact ${ }^{4}$, although the same impact can often be simulated using coastal atmospheric temperatures ${ }^{43}$. There has also been recent acknowledgement that phenological shifts are often a response to a wider range of climatic factors, including but not limited to frost, days above a certain threshold temperature, ENSO, and rainfall in the case of terrestrial species ${ }^{4-46}$, and photoperiod ${ }^{47}$, upwelling dynamics ${ }^{40}$, and lunar tidal $\mathrm{cycles}^{48}$, in addition to a range of intrinsic factors, for oceanic species. This study demonstrates poor correlation between the arrival date of sardines and SST. However, the delay in arrival date occurs concurrently with a poleward shift in the mean annual $21^{\circ} \mathrm{C}$ isotherm. The poleward shift in this $21^{\circ} \mathrm{C}$ isotherm, representing the threshold temperature boundary for sardine range ${ }^{21}$, could explain the trend towards a later migration date, and possible failure of the event all together, along parts of the southeastern African coastline. After such a date, the narrower temporal window of temperatures below $21^{\circ} \mathrm{C}$ would be experienced northeast of the sardines' summer habitat.

The association between later migration dates and lower numbers of mid-latitude cyclones in the austral autumn months of April and May further demonstrates the importance of secondary effects to the regional scale warming in constraining sardine arrival dates. Mid-latitude cyclone frequency apparently also controls the magnitude of the range shift of sardines in the North Pacific Ocean, through coupled temperature decreases and an enhanced overturning of surface waters. ${ }^{32}$ Long-term changes in the cyclogenesis of these systems through an expansion of the Hadley cell region should be investigated further ${ }^{49,50}$, given the significance of these systems for the sardine run. Although advances in spring phenological events are commonly reported as a response to climate change, delays in phenology have also been calculated among a range of plant and animal species even where species and methodology for data collection and analysis have been standardised. ${ }^{2,6}$ Menzel et al. ${ }^{51}$ argue that the relatively low rate of reporting phenological delays in scientific literature relates to biases in both the analysis and publication of data sets that do not conform to the expected trend. Moreover, in the case of autumn phenological events (which the sardine run represents), recent analyses for the northern hemisphere indicate that a delay may be the more common response, at least among plant species. ${ }^{52}$

While there is no statistical correlation between the arrival date and the MEl, the occurrences of good and poor sardine runs coincide very closely with El Niño and La Niña events, respectively - a similar result to that found for sardine migration patterns in the Pacific Ocean ${ }^{32}$ and sardine recruitment off Chile ${ }^{30}$. It is notable, however, that not all of the strongest El Niño events correspond with the failed sardine runs, neither do all of the instances of failed sardine runs correspond with peaks in MEl scores. Thus, phenological shifts in the timing of faunal migrations in the southwest Indian Ocean are driven by a more complex set of oceanatmospheric variables than that used to account for the more extensively documented changes in plant phenology, including but not limited to a

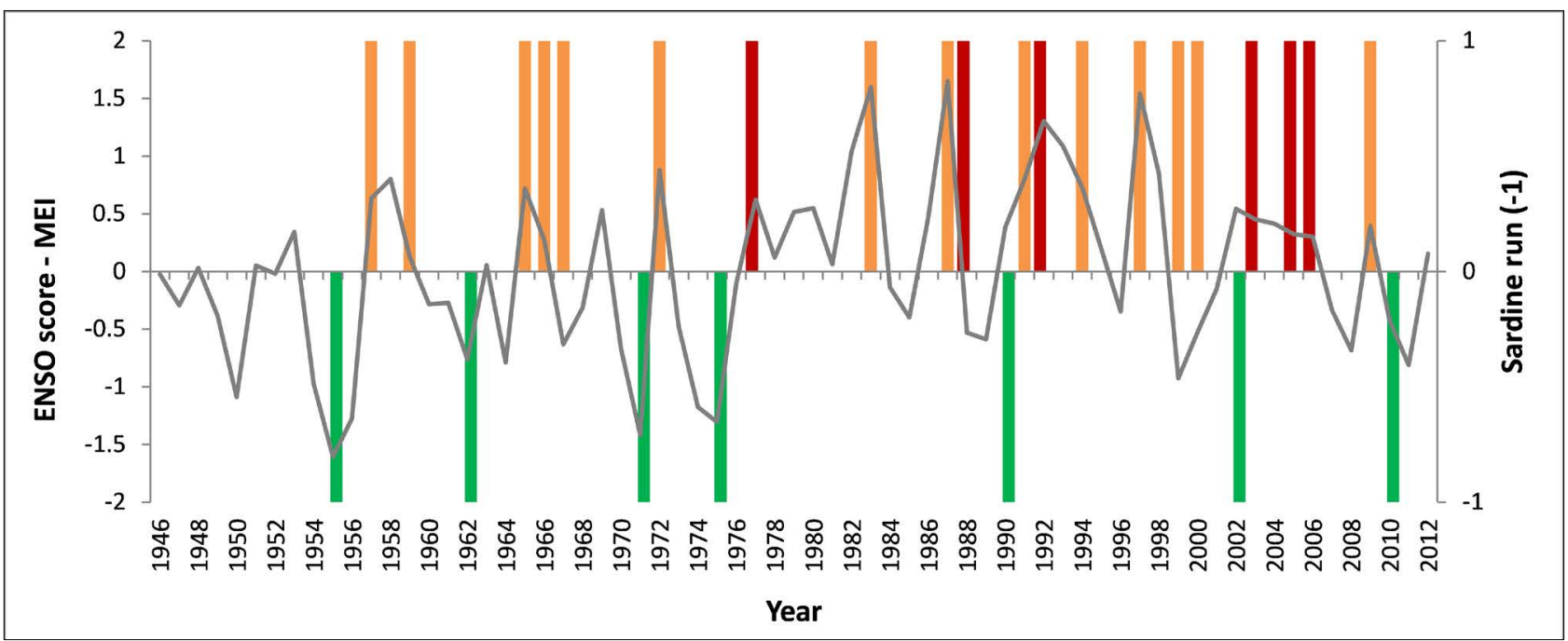

Figure 5: Multivariate ENSO Index (MEI) score (grey line; positive indicating El Niño events, negative indicating La Niña events) and the years of good (green bar, negative $y$-score), poor (orange bar, positive $y$-score) and non-existent (red bar, positive $y$-score) sardine runs. 
lagged ENSO effect, mid-latitude cyclones and SST, and are thus more difficult to statistically quantify. An important avenue for future research would include a detailed analysis of the sardine runs during strong El Niño and La Niña events, including total catch size, the experiences of fishers in the region, and a comparison with sub-daily oceanographic and meteorological data through the period of those runs.

Looking forward, three key factors are of concern. The first, in the short term, is the variability in timing of the sardine run, and the consequent lack of predictability which can have a detrimental effect on the fishing and tourism sectors of the Durban region. ${ }^{21,34}$ While this study confirms and quantifies the rate of delay in arrival date, this shift is coupled with a significant increase in the variability in arrival dates and recent failure of arrivals. Although a more comprehensive suite of ocean-atmospheric factors driving this shift are presented in this study than in former analyses of sardine run variability, this comprehensiveness does not necessarily afford a greater predictive strength for the timing of migration. Considerable environmental modelling would thus be required, coupled with real-time input of mid-latitude cyclones and the associated surface pressure fluctuations within the region, Agulhas current eddies, and MEI data to provide reliable seasonal forecasting of the arrival date. In the medium term, the increased incidence and last few years of failed runs presented in this study is of concern. ${ }^{20}$ It is unclear from the records available whether these incidents of failed runs represent a year in which the population did not migrate from the Agulhas Bank, a run in which the migration did not extend as far northeast as the Durban region, or a run which was thermally restricted to deeper waters, and thus not visible from the coastline. ${ }^{20}$ However, should this trend continue, it would heighten the probability that the run may have collapsed altogether, or shifted considerably further south. ${ }^{53}$ The delayed timing in the short term and possible collapse of the migration pattern in the long term present a third concern at an ecosystem scale, which relates to the predatorprey mismatches which may ensue. ${ }^{9,27,53}$ Improved observation of the concurrent phenological and range shifts among shark populations in the region, and changes in the abundance of phytoplankton, should thus be carefully monitored. ${ }^{23}$

This record highlights the significance of indirect ocean-atmospheric changes under conditions of global warming in constraining phenological and range shifts. This result heightens the importance of understanding phenological shifts among a diverse range of species, and across a large range of terrestrial and marine environments, to better understand the rate of phenological shifts, the intrinsic and extrinsic drivers, and the prospects for the species under sustained warming.

\section{Authors' contributions}

H.P. and S.W.G. collected the data. H.P. and J.M.F. conducted the statistical analysis. J.M.F. wrote the first draft of the manuscript. H.P. and S.W.G. provided input on the first draft.

\section{Acknowledgement}

We appreciate the sharing of ideas and suggestions provided by Dr Sean O'Donoghue during the early stage of this investigation.

\section{References}

1. Schwartz MD. Advancing to full bloom: Planning phenological research for the 21st century. Int J Biometeorol. 1999;42:113-118. https://doi.org/10.1007/ s004840050093

2. Parmesan $\mathrm{C}$, Yohe $\mathrm{G}$. A globally coherent fingerprint of climate change impacts across natural systems. Nature. 2003;421(6918):37-42. https:// doi.org/10.1038/nature01286

3. Root TL, Price JT, Hall KR, Schneider SH, Rosenzweig C, Pounds JA. Fingerprints of global warming on wild animals and plants. Nature. 2003;421(6918):57. https://doi.org/10.1038/nature01333

4. Poloczanska ES, Brown CJ, Sydeman WJ, Kiessling W, Schoeman DS, Moore PJ, et al. Global imprint of climate change on marine life. Nat Clim Change. 2013;3:919-925. https://doi.org/10.1038/nclimate1958
5. Chambers LE, Altwegg R, Barbraud C, Barnard P, Beaumont LJ, Crawford RJM, et al. Phenological changes in the southern hemisphere. PLoS ONE. 2016;8(10), e75514, 12 pages. https://doi.org/10.1371/journal.pone.0075514

6. Fitchett JM, Grab SW, Thompson DI. Plant phenology and climate change: Progress in methodological approaches and application. Prog Phys Geog. 2015;39(4):460-482. https://doi.org/10.1177/0309133315578940

7. Hegland SJ, Nielsen A, Lázaro A, Bjerknes AL, Totland Ø. How does climate warming affect plant-pollinator interactions? Ecol Lett. 2009;12(2):184-195. https://doi.org/10.1111/j.1461-0248.2008.01269.x

8. Rafferty NE, Ives AR. Effects of experimental shifts in flowering phenology on plant-pollinator interactions. Ecol Lett. 2011;14(1):69-74. https://doi. org/10.1111/j.1461-0248.2010.01557.x

9. Edwards M, Richardson AJ. Impact of climate change on marine pelagic phenology and trophic mismatch. Nature. 2004;430(7002):881-884. https:// doi.org/10.1038/nature02808

10. Durant JM, Hjermann DØ, Ottersen G, Stenseth NC. Climate and the match or mismatch between predator requirements and resource availability. Clim Res. 2007;33(3):271-283. https://doi.org/10.3354/cr033271

11. Visser ME, Holleman LJ, Gienapp P. Shifts in caterpillar biomass phenology due to climate change and its impacts on the breeding biology of an insectivorous bird. Oecologia. 2006;147:164-172. https://doi.org/10.1007/ s00442-005-0299-6

12. Saino N, Ambrosini R, Rubolini D, Von Hardenberg J, Provenzale A, Hüppop $\mathrm{K}$, et al. Climate warming, ecological mismatch at arrival and population decline in migratory birds. Philos T Roy Soc B. 2011;278(1707):835-842. https://doi.org/10.1098/rspb.2010.1778

13. Parmesan C. Influences of species, latitudes and methodologies on estimates of phenological response to global warming. Glob Chang Biol. 2007;13(9):1860 1872. https://doi.org/10.1111/j.1365-2486.2007.01404.x

14. Walther GR, Post E, Convey P, Menzel A, Parmesan C, Beebee TJ, et al. Ecological responses to recent climate change. Nature. 2002;416(6879):389395. https://doi.org/10.1038/416389a

15. Cotton PA. Avian migration phenology and global climate change. Proc Natl Acad Sci USA. 2003;100(21):12219-12222. https://doi.org/10.1073/ pnas. 0400920101

16. Alerstam T, Hedenström A, Åkesson S. Long-distance migration: Evolution and determinants. Oikos. 2003;103(2):247-260. https://doi.org/10.1034/j.16000706.2003.12559.x

17. Hurlbert $\mathrm{AH}$, Liang Z. Spatiotemporal variation in avian migration phenology: Citizen science reveals effects of climate change. PLoS ONE. 2012;7(2), e31662, 11 pages. https://doi.org/10.1371/journal.pone.0031662

18. Sparks TH, Carey PD. The responses of species to climate over two centuries: An analysis of the Marsham phenological record, 1736-1947. J Ecol. 1995;83(2):321-329. https://doi.org/10.2307/2261570

19. Gibbs JP, Breisch AR. Climate warming and calling phenology of frogs near Ithaca, New York, 1900-1999. Conserv Biol. 2001;15(4):1175-1178. https://doi.org/10.1046/j.1523-1739.2001.0150041175.x

20. Fréon $P$, Coetzee JC, Van der Lingen $C D$, Connell AD, O'Donoghue $S H$, Roberts MJ, et al. A review and tests of hypotheses about causes of the KwaZulu-Natal sardine run. Afr J Mar Sci 2010;32(2):449-479. https://doi.or $\mathrm{g} / 10.2989 / 1814232 x .2010 .519451$

21. O'Donoghue SH, Drapeau L, Dudley SF, Peddemors VM. The KwaZuluNatal sardine run: Shoal distribution in relation to nearshore environmental conditions, 1997-2007. Afr J Mar Sci. 2010;32(2):293-307. https://doi.org $/ 10.2989 / 1814232 \times .2010 .501587$

22. O'Donoghue SH, Drapeau L, Peddemors VM. Broad-scale distribution patterns of sardine and their predators in relation to remotely sensed environmental conditions during the KwaZulu-Natal sardine run. Afr J Mar Sci. 2010;32(2):279 291. https://doi.org/10.2989/1814232x.2010.501584

23. Connel AD. A 21-year ichthyoplankton collection confirms sardine spawning in KwaZulu-Natal waters. Afr J Mar Sci. 2010;32(2):331-336. https://doi.org/10. 2989/1814232x.2010.502638

24. Jury MR, Valentine HR, Lutjeharms JRE. Influence of the Agulhas Current on summer rainfall along the Southeast Coast of South Africa. J Appl Meteorol. 1993;32:1282-1287. https://doi.org/10.1175/15200450(1993)032<1282:iotaco>2.0.co;2 
25. Roffe SJ, Fitchett JM, Curtis CJ. Classifying and mapping rainfall seasonality in South Africa: A review. S Afr Geogr J. 2019;101(2):158-174. https://doi.org/1 0.1080/03736245.2019.1573151

26. Biastoch A, Böning CW, Schwarzkopf FU, Lutjeharms JRE. Increase in Agulhas leakage due to poleward shift of southern hemisphere westerlies. Nature. 2009;462:495-498. https://doi.org/10.1038/nature08519

27. Hutchings L, Morris T, Van Der Lingen CD, Lamberth SJ, Connell AD, Taljaard $\mathrm{S}$, et al. Ecosystem considerations of the KwaZulu-Natal sardine run. Afr J Mar Sci. 2010;32(2):413-421. https://doi.org/10.2989/1814232x.2010.502644

28. Alheit J, Hagen E. Long-term climate forcing of European herring and sardine populations. Fish Oceanogr. 1997;6(2):130-139. https://doi.org/10.1046/ j.1365-2419.1997.00035.x

29. Alheit J, Pohlmann T, Casini M, Greve W, Hinrichs R, Mathis M, et al. Climate variability drives anchovies and sardines into the North and Baltic Seas. Prog Oceanogr. 2012;96:128-139. https://doi.org/10.1016/j.pocean.2011.11.015

30. Gomez F, Montecinos A, Hormazabal S, Cubillos LA, Correa-Ramirez M, Chavez FP. Impact of spring upwelling variability off southern-central Chile on common sardine (Strangomera bentincki) recruitment. Fish 0ceanogr. 2012;21(6):405414. https://doi.org/10.1111/j.1365-2419.2012.00632.x

31. Chavez FP, Ryan J, Lluch-Cota SE, Niquen M. From anchovies to sardines and back: Multidecadal change in the Pacific Ocean. Science. 2003;299:217-221. https://doi.org/10.1126/science.1075880

32. Auth TD, Daly EA, Brodeur RD, Fisher JL. Phenological and distributional shifts in ichthyoplankton associated with recent warming in the northeast Pacific Ocean. Glob Chang Biol. 2018;24(1):259-272. https://doi.org/10.1111/ gcb.13872

33. Checkley Jr DM, Asch RG, Rykaczewski RR. Climate, anchovy, and sardine. Ann Rev Mar Sci. 2017;9:469-493. https://doi.org/10.1146/annurevmarine-122414-033819

34. Dicken ML. Socio-economic aspects of boat-based ecotourism during the sardine run within the Pondoland Marine Protected Area, South Africa. Afr J Mar Sci. 2010;32(2):405-411. https://doi.org/10.2989/1814232x.2010.502642

35. Fitchett JM, Grab SW. A 66-year tropical cyclone record for south-east Africa: Temporal trends in a global context. Int J Climatol. 2014;34(13):3604-3615. https://doi.org/10.1002/joc.3932

36. Fitchett JM. Recent emergence of CAT5 tropical cyclones in the South Indian Ocean. S Afr J Sci. 2018;114(11/12):83-88. https://doi.org/10.17159/ sajs.2018/4426

37. Sims DW, Wearmouth VJ, Genner MJ, Southward AJ, Hawkins SJ. Lowtemperature-driven early spawning migration of a temperate marine fish. J Anim Ecol. 2004;73:333-341. https://doi.org/10.1111/j.0021-8790.2004.00810.x

38. Kaltenberg AM, Emmett RL, Benoit-Bird KJ. Timing of forage fish seasonal appearance in the Columbia River plume and link to ocean conditions. Mar Ecol Prog Ser. 2010;419:171-184. https://doi.org/10.3354/meps08848

39. Jansen T, Gislason $H$. Temperature affects the timing of spawning and migration of North Sea mackerel. Cont Shelf Res. 2011;31:64-72. https://doi. org/10.1016/j.csr.2010.11.003
40. Asch RG. Climate change and decadal shifts in the phenology of larval fishes in the California CurrentEcosystem. Proc Natl Acad SciUSA. 2015;112(30):40654074. https://doi.org/10.1073/pnas.1421946112

41. Beckley LE, Van der Lingen CD. Biology, fishery and management of sardines (Sardinops sagax) in southern African waters. Mar Freshwater Res. 1999;50(8):955-978. https://doi.org/10.1071/mf99068

42. Botsford $\mathrm{LW}$, Castilla JC, Peterson $\mathrm{CH}$. The management of fisheries and marine ecosystems. Science. 1997;277(5325):509-515. https://doi.org/10.1126/ science.277.5325.509 .

43. Morley JW, Batt, RD, Pinsky ML. Marine assemblages respond rapidly to winter climatic variability. Glob Change Biol. 2016;23:2590-2601. https://doi. org $/ 10.1111 / g c b .13578$

44. Peñuelas J, Filella I, Zhang X, Llorens L, Ogaya R, Lloret F, Comas P, Estiarte M, Terradas J. Complex spatiotemporal phenological shifts as a response to rainfall changes. New Phytol. 2004;161(3):837-846. https://doi.org/10.1111/j.14698137.2004.01003.x

45. Crimmins TM, Crimmins MA, Bertelsen DC. Complex responses to climate drivers in onset of spring flowering across a semi-arid elevation gradient. J Ecol. 2010;98(5):1042-1051. https://doi.org/10.1111/j.1365-2745.2010.01696.x

46. Fitchett JM, Grab SW, Thompson DI, Roshan G. Spatio-temporal variation in the phenological response of citrus to climate change in Iran: 1960-2010. Agr Forest Meteorol. 2014;198-199:285-293. https://doi.org/10.1016/j. agrformet.2014.08.010

47. Pankhurst NW, Porter MJR. Cold and dark or warm and light: Variations on the theme of environmental control of reproduction. Fish Physiol Biochem. 2003;28:385-389. https://doi.org/10.1023/b:fish.0000030602.51939.50

48. Samoilys M. Periodicity of spawning aggregations of coral trout Plectropomus leopardus (Pisces: Serranidae) on the northern Great Barrier Reef. Mar Ecol Prog Ser. 1997;160:149-159. https://doi.org/10.3354/meps160149

49. Lu J, Vecchi GA, Reichler T. Expansion of the Hadley cell under global warming. Geophys Res Lett. 2007;34(6), L06805, 5 pages. https://doi. org/10.1029/2006GL028443

50. Seidel DJ, Fu Q, Randel WJ, Reichler TJ. Widening of the tropical belt in a changing climate. Nat Geosci. 2008;1(1):21-24. https://doi.org/10.1038/ nge 0.2007 .38

51. Menzel A, Sparks T, Estrella N, Koch E, Aasa A, Ahas R, et al. European phenological response to climate change matches the warming pattern. Glob Change Biol. 2006;12:1969-1976. https://doi.org/10.1111/j.13652486.2006.01193.x

52. Liu Q, Fu YH, Zhu Z, Liu Y, Liu Z, Huang M, et al. Delayed autumn phenology in the northern hemisphere is related to change in both climate and spring phenology. Glob Change Biol. 2016;22(11):3702-3711. https://doi.org/10.1111/gcb.13311

53. Kovach RP, Joyce JE, Echave JD, Lindberg MS, Tallmon DA. Earlier migration timing, decreasing phenotypic variation, and biocomplexity in multiple salmonid species. PLoS ONE. 2013;8(1), e53807, 10 pages. https://doi.org/10.1371/ journal.pone.0053807 